\title{
Sacrifice - Action within a Relationship: A Phenomenology of Sacrifice
}

\author{
Claudia Mariéle Wulf
}

A young woman had become entangled in drug culture. Nothing had warned her about the consequences of drug abuse for the rest of her life, nor about the effects it was to have on her parents and younger sister. She had closed herself off from her family and friends, so her mother had no longer any access to her. Her mother prayed. This, however, was not enough. Slowly but surely, the mother began to change. First, she stopped eating what she most enjoyed. It was a silent offering for her daughter, who failed to understand. Instead, the girl replied: “It doesn't affect me whether you eat what you like or not!". Then her mother started copying her daughter's way of dressing. She roamed the streets in old and shabby shoes, she dyed her hair black like her daughter had done, something which was quite alien to herself. Initially, her daughter just laughed at her. Then she fell silent. She knew what it meant to her mother to be a laughing stock for the people, because of her shoddy appearance. When she fully realized that her mother had made these sacrifices in order to show her how close she was to her, her mother's love touched her and she returned home.

Is this the sort of sacrifice we are talking about here? Does sacrifice mean giving up yourself in order to save somebody else? Does it mean offering yourself as a sacrifice to God? Does God want - or even ask for - such sacrifice? The example shows that in order to be meaningful, a sacrifice has to be related to someone: To God, or to another human being. It can also be related to creation, if creation is seen as a responsibility given to us by God. To make a sacrifice means giving up something important, something we like or love, in order to reach a higher goal.

Sacrifices abound in everyday life. We find them in ecological groups, for example, where members decide to save energy and consciously refrain from enjoying some pleasures in order to save the environment. We find another kind of sacrifice in a movement of young people who seriously try to postpone intimate relationships until they meet the right partner, someone with whom they want to share intimacies for the rest of their lives. ${ }^{1}$ We also find it in sport

1 See http://www.lifeway.com/Article/true-love-waits. Consulted on October 31, 2011. 
and profession, where people give up everything in order to reach their goal. We often forget that parents live lives filled with sacrifice, in order to bring up their children in the best possible way. It is not uncommon for parents to give up professional advancement, if this can positively affect the development of their children.

\subsection{Sacrifice-An All-Embracing Concept}

A gift can entail sacrifice. A person can sacrifice himself or herself in freedom. ${ }^{2}$ However, if someone is being sacrificed without consenting to it, that person does not act voluntarily and hence becomes a victim. If a thing (or in some cults an animal) is sacrificed, we call it an oblation. To sacrifice means consciously letting go of something that is important, valuable or pleasurable, because it is meaningful to do so. It is essential, therefore, that there are good reasons for making a sacrifice - it is a means to an end. What one gets or attains is not part of what one gives or gives up; it is not a sacrifice if we give up something or someone we wanted to get rid of anyway. It should be done for the sake of a higher goal, just as the mother in our example gave up food and nice clothing as well as her social reputation, in order to restore her daughter's health. When somebody makes a sacrifice in this way, it is voluntary. Life may often require sacrifices from us. If we cannot accept such a sacrifice as part of our life, if we cannot make the sacrifice freely, we may become a victim ourselves. A sacrifice, in order to be a true sacrifice, has to be made in freedom. ${ }^{3}$

A sacrifice is part of an interpersonal relationship - someone sacrifices something for the sake of another person. This can be done, and often is done, without the knowledge of the person concerned. It can take place in the context of reconciliation: If the guilty party is unable to make amends, someone else can do this on his or her behalf and thus bring about reconciliation. This happens in a religious, social, or political context.

The opposite attitude to the readiness to make a sacrifice is consumerism. ${ }^{4}$ This attitude presupposes that everything has to be available here and now,

2 In new myths, like Harry Potter (J. K. Rowlings) and Lord of the Rings (J. R. R. Tolkien), the protagonist offers himself as a sacrifice, but survives. See Almuth Hammer, "Dein Leben ist das meine wert. Erlösungsmythen in der Fantasy," in Erlösung ohne Opfer? (ed. Werner H. Ritter; Göttingen: Vandenhoek \& Ruprecht, 2003), 157-192. See also the contribution by Sigrid Coenradie on Harry Potter in this volume.

3 See Wolfgang Palaver, René Girards mimetische Theorie. Im Kontext kulturtheoretischer und gesellschaftspolitischer Fragen (Münster-Hamburg-London: LIT, 2004), 293.

4 See Claudia Mariéle Wulf, Der Mensch - ein Phänomen. Eine phänomenologische, theologische und ethische Anthropologie (Vallendar: Patris, 2011), 402. 
and preferably should cost very little. It means finding our bearings solely with a view to our own wishes and ideas. This is the basic attitude of many in our present-day society, but life is impossible without sacrifices, as we shall see later.

\section{Part I. Four Core Values of Sacrifice as an Action within Relationship}

Before I deal with the view of Edith Stein on sacrifice (part 2), I will offer a short phenomenology of sacrifice as an action within a relationship from four points of view.

1. A sacrifice is a free act. This is the philosophical and psychological aspect.

2. Sacrifice has a social function. Hence it can be seen in sociological terms. This aspect has been developed among others by René Girard, ${ }^{5}$ and has been developed further by Raymund Schwager sJ into his Dramatic Theology. ${ }^{6}$

3. Sacrifice may include the dimension of creation.

4. Finally, there is a theological element to sacrifice.

\subsection{Ad 1. Sacrifice from a Psychological Perspective: A Free Act}

First I would like to describe some psychological aspects of sacrifice. A sacrifice is an action, that is, the expression of free choice. In comparison with other actions, it is an expression of greater freedom. In the normal course of events, our actions are motivated by some value we want to attain or protect. This value is directly connected with the action or the object of an action. Sacrifice is also orientated to a value, but it is not immediately contained in it, or attainable at the moment. Sometimes we cannot be sure that we will attain the object of the action. The mother in the example could not know whether her daughter would be brought back from the way she had chosen. The value that is aimed at is only indirectly related to the sacrificial action; it is often just

5 See René Girard, Violence and the Sacred. (tr. P. Gregory; Baltimore:The Johns Hopkins University Press, 1977) and René Girard, Le sacrifice (Paris: Bibliothèque Nationale de France, 2003).

6 See Raymund Schwager s.j. and Józef Niewiadomski, eds, "Dramatische Theologie als Forschungsprogramm," in Religion erzeugt Gewalt; Einspruch! Innsbrucker Forschungsprojekt Religion-Gewalt-Kommunikation-Weltordnung (Beiträge zur mimetischen Theorie, Band 15; Münster-Hamburg-London: LIT, 2003), 39-77, 57; Raymund Schwager SJ, Jesus in the Drama of Salvation: Toward a Biblical Doctrine of Redemption (New York: Crossroad, 1999). 
the expression of hope. It follows that a sacrifice is a greater expression of freedom, because it means detaching ourselves from the good being aimed at, and from the possible satisfaction of what is desired. If we make the sacrifice, we give up something in order to attain a higher goal, although we can only hope that we will attain it.

In a certain sense, when we bring a sacrifice we become the victim of our own sacrifice. We deprive ourselves of something. This can even go so far that we do not just sacrifice something, but our very self. The sacrifices made by the mother in our opening example come close to the self-sacrifice meant here. If we become a victim of our own sacrifice, it means we have accepted sacrificing our very self. Such a sacrifice may not be undertaken without that acceptance. This is because if we give up ourselves without realizing it, we abuse ourselves for an external goal. We may then lose ourselves, because by giving up ourselves and our freedom our soul is wounded. We may later feel that we have become ourselves the victim of the cause for which we had initially sacrificed ourselves. If the daughter in the example had not come home again, her mother could have felt she was her daughter's victim; she could then have accused her daughter of ingratitude and hardness of heart. This shows clearly that an action, which should actually have been undertaken freely and willingly, runs the risk of becoming no longer the expression of something freely willed; instead it is perceived as having been forced upon oneself by another person. Any relationship to a personal decision has then been lost.

Making a sacrifice does not guarantee that we will actually attain the higher goal. If we decide to make a sacrifice, to give up something, we must be aware of this. To sacrifice means giving up something of value, to let go of something one has possessed, and hence to give up the security connected with it. Since we can never be sure that the higher value will be achieved, sacrifice includes giving up a temporary, sometimes only supposed security, in order to attain a higher goal, a greater or even ultimate security.

If we freely and willingly make a sacrifice, we remain in relationship with ourselves, with our own will. However, if on the contrary a sacrifice is demanded of us, it can destroy our relationship to our self. The only possibility that remains is to agree to and accept the sacrifice afterwards, and to assimilate it as part of our own life. In this way the sacrifice remains part of our own freedom, and we remain in relationship to ourselves. This is one of the highest possibilities of human freedom. This act of freedom restores our relationship to ourselves in view of an action that is demanded of us. So if I feel that I am the victim, because a sacrifice has been demanded of me, and then decide freely and willingly to give, or give up what is demanded of me, I can experience that such a sacrifice liberates me from a situation of bondage. 


\subsection{Ad 2. Sociological Aspect of Sacrifice-Our Relationship to Others}

Until now sacrifice has been considered in relation to the self. Let us take a second step and examine it in relation to others. I will mention two forms of sacrifice in this regard: A synchronic sacrifice for someone who is present at the same time and place, and a diachronic sacrifice that benefits those who lived in the past, or will live in the future, and/or at another place.

\subsection{A Synchronic and Local Sacrifice}

Our daily sacrifices are usually synchronic with the people who live around us, or at least at the same time. For example, we can sacrifice something for someone we love.

The fundamental attitude of consumerism, which demands that everything is here, now, immediately and completely available, destroys human relationships: The other person is not here in reality, he or she is usually somewhere else. This means that I have to give up my 'here' in order to meet the other person. The other person is not immediately at my disposal, he or she does things differently, so I have to give up my idea of 'now' in order to give the other person time and space to act. With children, for example, we have to scale back our own pace of doing things. The other person is not perfect, never quite in accord with our criteria - he or she is always different from what we expect. We have to give up our own picture of that person, or we will never discover the richness of his or her personality. In relationships nothing is free, we have to make some sacrifices in order to be unexpectedly enriched.

In human relationships, it is impossible to maintain the attitude of consumerism, which is antithetical to sacrifice - we have to give up something, even if we might have considered it valuable, if we really want to encounter the other person. We see that such a sacrifice is usually required when we encounter someone directly - our partner, our children, our friends, the significant people around us. It is a sacrifice that takes place simultaneously with an encounter, and often at the same place. Its aim is the sense of well-being of the people in our vicinity.

\subsection{A Diachronic and Global Sacrifice}

However, a sacrifice can also be important with reference to other times, that is, diachronically. It can play an important role in historical relationships; for example, if we need to be reconciled with our past. It is possible today to contribute through a symbolic act to a reconciliation that has not yet taken place. The need of reconciliation arises from a crime or misdeed in the past; however, it is ultimately directed to a reconciliation in the future, so it is directed 
towards the future. Hans Jonas mentions the duty to live in such a way today to make sacrifices today - that a future generation can exist:

Existenz der Menschheit heißt einfach: Dass Menschen leben; dass sie gut leben, ist das nächste Gebot. Das nackte ontische Faktum, dass es sie überhaupt gibt, wird für die darin vorher nicht Befragten zum ontologischen Gebot: Dass es sie weiter geben soll. Dies an sich namenlos bleibende "erste Gebot" ist ungesagt in allen weiteren enthalten (wenn diese nicht das Nichtsein zu ihrer Sache gemacht haben). ${ }^{7}$

In this sense sacrifice is orientated to something that might not even happen, so it is borne from hope. The past plays no role (unless we have to work off inherited issues in the present, in order to make the future possible); the goal of sacrifice is to be found in the future.

This form of sacrifice can be global in nature. We do today, here and now, what could bear fruit tomorrow or somewhere else. It is possible to have the whole world in view, for example, if we sacrifice our freedom of movement in order to reduce the emission of greenhouse gas. In addition, by acting in this way we can offer others a good example, and thus perhaps change a situation for the better.

\subsection{Ad 3. Sacrifice Seen Ecologically - in Relation to Creation}

The example quoted above shows clearly that sacrifice is not only directed to people, it can also be related to creation. Let me again refer to an idea of Hans Jonas: The duty to make it possible for future generations to live includes the duty to ensure that a world exists in which people can live. We have to give up something that we might wish to wrest from creation - also here we have to give up the attitude of consumerism - so that other people who come after us can live. We cannot expect that the goods we require are always 'here' they have to be transported long distances in order to be available. We need an ancient virtue that requires sacrifice of us: Temperance. It is impossible for

7 See Hans Jonas, Das Prinzip Verantwortung. Versuch einer Ethik für die technologische Zivilisation (Frankfurt am Main: Suhrkamp, 2003), 186-87: "The human existence simply means: that people live; that they live righteously, is a commandment which comes next. The pure ontological fact that they exist at all, becomes an ontological commandment for those who were never questioned beforehand: that they must go on existing. This, in itself nameless, 'first commandment' is silently taken up in all that follows (as long as it does not make non-being its aim". 
everything to be at our disposal all the time; not every fruit grows in every season. Instead of organizing things to be conveyed around the world, so that we can enjoy fruits that are out of season, we should practice patience, another virtue that requires sacrifice of us. It is not possible for everything to be available all the time - we must again become modest and frugal in our wants, which, again, requires sacrifice of us. Things are not always exactly the way we want them to be - some of our wishes have to be given up; flexibility is required. Finally, it is not possible for everything to be as cheap as we would wish if the regulations to protect the environment (and social justice) are to be observed through our own diligence we have to purchase the things that do not just fall into our laps. The subject of sacrifice, therefore, is very topical when we look at the whole problem of the environment.

\subsection{Philosophical Sacrifice}

Does philosophy require sacrifice? It is probably a provocative idea. Philosophy seems to be the field in which we have full scope for our thinking without observing any limits. Are our thoughts not free? Yes and no! Capriciousness in thinking, which does not include practical consequences, is dangerous. (A well-known example is Peter Singer, who became famous because of his provocative anthropology and his ideas on animal liberation, ${ }^{8}$ in fact ignoring pratical implications. Are we allowed to express such ideas and confuse those people who are unable to expose the philosophical lapses? Has someone like Singer thought about the fact that as a result of his ideas someone could harm another person, or that the disabled could be insulted and harmed by his theories - what actually happened? We have to take responsibility for our thoughts and ideas.)

The sacrifice of the intellectual is the sacrifice of a self-created truth. The intellectual or academic has to orientate his or her search to the objective truth, and this sometimes requires them to sacrifice their own ideas, because they are too far removed from the truth - no matter how evocative their ideas may be or how much fame they could bring. What is demanded here is the sacrifice of capriciousness and intellectual vanity.

In general, knowledge has always to distance itself from what could still be done in order to gain power, prestige and riches. The pressure exerted on science by those providing the funding often enough counters the actual goal of science. Precisely in the field of science sacrifice may be totally 'un-modern', but it is sometimes necessary in order to protect the truth and the world from intellectual hubris and the delusion of feasibility.

8 See Peter Singer, Practical Ethics (Cambridge: University Press, 2011). 
In this regard, Edith Stein offers an interesting thought. She speaks about the "sacrifice of one's own intellect", which has to be made in order to understand a greater truth. Her insight was that human beings can only understand the world and themselves to a certain degree; what transcends the human intellect and touches the divine can only be given to human beings as a gift. ${ }^{9}$

\subsection{Sacrifice Seen Theologically - A Gift to God}

The fourth and last element related to sacrifice is the theological context of sacrifice when it is offered to God. From a phenomenological viewpoint, religions see sacrifice as offering something to God. In ancient and in natural religions, it is taken for granted that the godhead demands sacrifice. In a magical-mystical context, a sacrifice becomes a gift that prevails upon the godhead, even forcing that godhead to grant what the human being requires of it. In the monotheistic religions, sacrifice is understood as a free gift to God, which cannot force God to do anything, but is nevertheless an expression of an urgent request, or else - and this is often forgotten - an expression of gratitude or praise. Sacrifice should not make people enslaved to God, but no more may it be misinterpreted as the price by which they can extract something from God, or force God to do something, in the sense of a quid pro quo. God remains free in this regard too.

In the context of religion, sacrifice is a free gift to God and an expression of human self-surrender to God. In this sense sacrifice is a conscious and free gift, and even an expression of human freedom in relation to a transcendent power.

The phenomenologist Edith Stein situated sacrifice within the context of mediation between God and man. The Mediator, the Redeemer, stands between God and human beings, making himself the victim in order to redeem us. This sacrifice was the outflow of Jesus Christ's free decision; he obeyed God's will in freedom and as an expression of freedom. ${ }^{10}$

Stein also wanted to see her own sacrifice in the sense of mediation. She saw herself as a mediator between God and the Chosen People, which had

9 See Edith Stein, Der Intellekt und die Intellektuellen. In: Bildung und Entfaltung der Individualität. (Edith Stein ESGA 16. Freiburg-Basel-Wien: Herder, 2001), 116-117, 143-156.

10 See Edith Stein, Natur, Freiheit und Gnade. Published as: "Die ontische Struktur der Person und ihre erkenntnistheoretische Problematik," in Welt und Person. Beitrag zum christlichen Wahrheitsstreben (ESW VI; Freiburg-Basel-Wien: Herder, 1962), 137-198 (160-162). 
not yet found their Messiah. ${ }^{11}$ According to Stein's understanding, her people had become partakers in the sufferings of Christ, without realizing whose cross they were carrying at that moment. ${ }^{12}$ They didn't know that their suffering already included their future redemption. Edith Stein stated that she wanted to bear the cross on behalf of her people, because, blessed by that cross (Benedicta a Cruce), she knew about the redemptive power of suffering and about the reconciliation needed. ${ }^{13}$

\subsection{God's Sacrifice}

In the context of religion, it is often overlooked that God personally offers sacrifice. ${ }^{14}$ God is both the Sacrificer and the Sacrifice, ${ }^{15}$ a sacrifice in which Jesus Christ himself became the Victim as a result of his own free decision. ${ }^{16}$ That is the unique quality of sacrifice in Christianity: God is present on both sides of the sacrifice. God is the redemptive Sacrifice and the One who accepts the sacrifice.

11 See Edith Stein, Testament (Edith Stein Archiv Köln, A55).

12 See Maria Amata Neyer and Andreas Uwe Müller, Edith Stein - das Leben einer ungewöhnlichen Frau (Düsseldorf: Benziger, 1998), 264-268 and 278-280, footnote 21.

13 See Waltraud Herbstrith, Edith Stein; ein neues Lebensbild in Zeugnissen und Selbstzeugnissen (Mainz: Topos, 1983), 153-154: "Ihr geistlicher Begleiter Johannes Hirschmann fragte sie: 'Wer sühnt für das, was am jüdischen Volk im Rahmen des deutschen Volkes geschieht? [...] Wer wendet die entsetzliche Schuld zum Segen für beide Völker?' Und sie antwortet damals: 'Die, die die Wunden, die hier der Hass schlägt, nicht neuen Hass gebären lassen, sondern die, obwohl sie mit Opfer des Hasses sind, das Leid unter den Gehassten und das Leid der Hassenden auf sich nehmen'."

14 See Wolfgang Schoberth, "Schlachtopfer gefallen dir nicht (Ps 40:7) Der Kreuzestod Jesu: Ein Opfer?," in Erlösung ohne Opfer? (ed. Werner H. Ritter; Göttingen: Vandenhoek \& Ruprecht, 2003), 83-112 (90).

15 See Joseph Ratzinger, „Einführung in das Christentum. Vorlesungen über das Apostolische Glaubensbekenntnis. (München: Kösel, 1968), 232: Nicht der Mensch ist es, der zu Gott geht und ihm eine ausgleichende Gabe bringt, sondern Gott kommt zum Menschen. (...) Das Neue Testament sagt nicht, dass die Menschen Gott versöhnen, wie wir es eigentlich erwarten müssten, da ja sie gefehlt haben, nicht Gott. Es sagt vielmehr, dass Gott in Christus die Welt mit sich versöhnt hat (2 Kor 5:19)“. See Claudia Mariéle Wulf, Begegnung, die befreit. Christliche Erlösung als Beziehungsgeschehen. (Vallendar: Patris, 2009), 212 and 238-240.

16 See Wolfgang Palaver, René Girards mimetische Theorie, 294. This is the difference with the scapegoat sacrifice on which Girard's theory is based. Girard later changed from «La violence et le sacré » to «De la violence à la divinité ». René Girard, De la violence à la divinité (Paris: Grasset, 2007). 
Through the Incarnation and Redemption, God, in a certain sense, sacrifices his own Godhead - a greater abasement cannot be imagined - because he renounces being seen as he really is: As God.

Through hishuman life, God took partin the everyday sacrifices of humanity. ${ }^{17}$ Through his death on the cross he did more than is possible for a human being: He took all human suffering upon himself, assimilating it into his sacrifice; $\mathrm{He}$ is the Victim that bears within himself every sacrifice throughout time and nails it to the cross, so that in the resurrection he could redeem everyone definitively and forever from suffering. Sacrificial gifting - not sacrificial being is the condition for creating an identity.

\subsection{Self-Unfolding and Sacrifice}

Some readers may have been taken aback by Edith Stein's idea of sacrificing the intellect. Is it possible to sacrifice one's intellect without losing oneself? A human being is a complex entity that is able to unfold or develop mind and body and emotions, both on an individual level and on a social and moral level (in freedom and responsibility), herewith even transcending his or her limitations.

Nevertheless, in actual life our humanity is limited: If one ability is developed, another has to be in abeyance. If we want to gain something, we necessarily have to give up something else. This is because we cannot do everything, limited as we are by space and time, even if we have the mental and physical endowment to do so. Even in order to develop our abilities in a chosen field, we have to sacrifice our strength and time. Unless we make these sacrifices, we will not make the best use of our possibilities.

\subsection{Integration of Personal Sacrifice}

The second task in view of sacrifice and identity is the integration of necessary sacrifices into our existence. This includes not just the self-chosen sacrifices, but even more so the sacrifices demanded of us and that we do not really want to make. Allowing ourselves to become a victim can alienate us from ourselves and our own personality. A clear example of this is being victimized: If someone becomes a victim to such an extent that he or she is no longer able to remember being anything else, and if this person interiorizes the fundamental attitude of being a victim so that he or she is unable to escape powerlessness, such a person will lose contact with his or her true self.

17 See Reinhard Feldmeier, “Gottes Torheit? Deutungen des Todes Jesu im Neuen Testament," in Erlösung ohne Opfer? (ed. Werner H. Ritter; Göttingen: Vandenhoek \& Ruprecht, 2003), 38. 
The positive integration of the status of a victim into one's existence can take place by accepting the sacrifice as described above; however, this free acceptance does not mean that the trauma resulting from victimization is overcome. Trauma is an obstacle to freedom, and can only be integrated into the personality once freedom is restored.

\subsection{No Life without Sacrifice - No Sacrifice of Life? Or Could it Be?}

No one who lives can escape sacrifice - sacrifice is an everyday reality. In Jesus Christ we encounter the highest form of sacrifice: To sacrifice oneself in freedom, and to accept the sacrifice even before it happens, which may be seen as the ultimate act of human freedom.

Edith Stein followed Christ along this way. She mirrored her own fate in that of Queen Esther, who was prevailed upon by her people to sacrifice herself. She approached the king of Persia as representative of her people to plead for its freedom. Just as Esther expected to be killed by entering the presence of the King without being commanded, so did Edith Stein expect her own death. ${ }^{18}$ Esther was allowed to live - Edith Stein was not. The free decision to act even when there is no choice has already been described as the highest form of freedom and sacrifice. In the face of death it is the highest and most perfect sacrifice we can make. By reinterpreting one's fate of an imposed sacrifice, and making it into a freely willed sacrifice, we can follow Christ and make meaningful what is senseless; we can experience resurrection in death. The last written note from Edith Stein, written on her way to Auschwitz, contains only a single sentence: "On the way ad orientem. Teresia Benedicta a Cruce. Edith Stein".19

Ad orientem - to the East. This liturgical concept alludes to the resurrection, the coming of the Messiah. By consciously choosing this Latin formula, she gave a final, impressive profession of faith. It is the expression of a freely willed sacrifice in the face of imminent death, which helps us to intuit that the deeper meaning of this sacrifice is the resurrection in messianic salvation.

18 See Edith Stein, Selbstbildnis in Briefen II, 1934-1942. ESW IX (eds L. Gelber and R. Leuven; Druten: De Maas \& Waler/Freiburg, Basel, Wien: Herder, 1977), letter nr. 281, 121.

19 "Unterwegs ad orientem. Teresia Benedicta a Cruce. Edith Stein." Witness of this last note was Sr. Placida Laubhardt (1904-1998); I interviewed her on this subject in January 1996. See further documentation: http://www.kloster-st-lioba.de/assets/sr-placidadokumation.pdf, consulted October 31, 2011. 